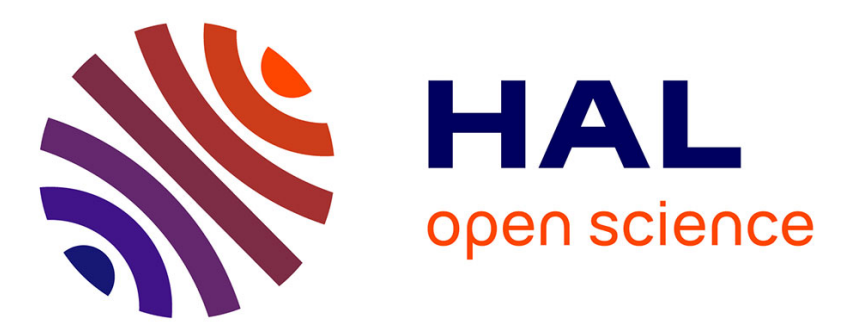

\title{
Institutional Project-Based Learning: Evidence from a Multi-actor e-Government Reform
}

Endrit Kromidha

\section{To cite this version:}

Endrit Kromidha. Institutional Project-Based Learning: Evidence from a Multi-actor e-Government Reform. 1st International Conference on Sustainable ICT, Education, and Learning (SUZA), Apr 2019, Zanzibar, Tanzania. pp.107-116, 10.1007/978-3-030-28764-1_13 . hal-02515747

\section{HAL Id: hal-02515747 \\ https://hal.inria.fr/hal-02515747}

Submitted on 23 Mar 2020

HAL is a multi-disciplinary open access archive for the deposit and dissemination of scientific research documents, whether they are published or not. The documents may come from teaching and research institutions in France or abroad, or from public or private research centers.
L'archive ouverte pluridisciplinaire HAL, est destinée au dépôt et à la diffusion de documents scientifiques de niveau recherche, publiés ou non, émanant des établissements d'enseignement et de recherche français ou étrangers, des laboratoires publics ou privés. 


\title{
Institutional Project-Based Learning: Evidence from a Multi-Actor e-Government Reform
}

\author{
Endrit Kromidha ${ }^{\text {[0000-0001-7872-6790] }}$ \\ University of Birmingham, Birmingham, UK \\ e.kromidha@bham.ac.uk
}

\begin{abstract}
This study contributes by providing a conceptual framework around learning in public administration reforms. Large e-government projects through which reforms are introduced often involve multiple organisations, they are complex, require a careful consideration of power and have a long institutional impact on society. Project-based learning (PBL) and institutional theory from public administration studies form the theoretical framework this study builds upon. Findings suggest that learning in public administration reforms in the context of a developing country is characterised by strategic, constructive and reflective practices that follow each other in cycle along project implementation stages. The unit of analysis in this study is project organisations instead of students or employees where project-based learning has been traditionally applied, making the contributions of this study unique and relevant not only for project managers, but also for policy makers, local policy leaders and international organisations.
\end{abstract}

Keywords: public sector, project-based learning, institutional theory, egovernment, developing country.

\section{Introduction}

Learning in the public sector can be a painful, but necessary process that happens between imitation and innovation [36]. There has been a growing interest in organizational learning in the public sector [12] as an approach to continuous improvement, knowledge acquisition, and creation. While Finger and Brand (1999) argue that public sector agencies should be transformed into learning organizations, they provide little evidence of how this happens in practice.

Recently there is a shift towards participatory public decision-making [20, 42] and open innovation [11]. Other innovation models in the public sector domain have become more focused by taking a closer look at projects [1], their risk management [19], agile configuration [6] and even investments [2]. The complexity of multiple overlapping projects has been followed by research on semantic models of shared knowledge management [47]. These approaches are extended even to user cantered models for rural development through e-government projects [27]. Policy intervention models in support of e-government for developing countries have also been attempted [5] by taking a best-practice perspective. 
Such previous studies, however, take for granted and do not say much about the learning process that takes place during most e-government innovation projects. This study intends to address this gap by adapting an institutional theory perspective on project-based learning perspectives to explore the following research question: How does institutional learning happens in internationally assisted e-government reforms for development?

\section{Institutional Theory and Project-Based Learning in e- Government}

According to March and Olsen [28, 29, 30, 31, 32, 35, 33, 34) an institution can broadly be described as an enduring collection of rules and practices around structures of meaning and resources [30]. Institutionalizing not only policy implementation changes, but also the very process that institutionalized them is a major issue of governance that often relates to project-based learning.

Although institutions are often resilient to change, they can be designed, especially in a political context, influenced by actors and preferred solutions in collective public choices [8, 9]. Interregional institutional learning is the next level where learning is presented along a cycle of encoding, conceptualization, operationalization, and experimentation between regions [14], a framework that differs little from an explanation of social exchanges [45]. More research in this later direction considers the transfers of power among e-government project actors [24] and adaptive power of social-ecological systems towards change, and conflict resolution [13]. Many of these studies are informed by the ideas of New Public Management (NPM) that tries to use business management concepts in the public sector context [10]. They conclude that learning in public administration reforms is not a simple transfer of knowledge from those who know more to those who know less, but rather a complex process dispersed among adaptation, exchanges, transformation, intermediation and acceptance.

Project-based learning (PBL) on the other hand focuses on learning around and from projects based on five criteria: centrality, questioning, constructive investigation, autonomy and realism [44]. A key principle of PBL is learning by doing [3]. The model has been successfully applied not only in classroom settings but also in workplaces to solve problems through learning projects [40]. Learning in workplace settings is characterised by a combination of organisational and individual spaces and processes [15, 16], taking a reflective and contextual approach [17]. Although PBL has traditionally been applied to classroom settings, there is scope for the model to be adapted to any project setting, building on existing research on learning in organisational settings. However, what is different in the context of e-government public sector reforms is the involvement of multiple and often temporarily-connected organisations connected by power relationships and institutional forces [24, 25]. The unit of analysis for learning in this case should be the project and the involved stakeholder organisations instead of one organisation and its employees or the teacher and student relationship in classroom settings.

PBL suggests that technology can support students and teachers as they work on projects to sustain motivation and thought [3]. These would be desirable outcomes in any e-government project reform aiming to institutionalize new practices among all 
project stakeholders and citizens. However, creativity, technology innovation and in general change presents a number of challenges and risks that in organizational settings are controlled through organizational structures [18], but building such learning organisations that can facilitate the smooth implementation of innovation and change projects is not easy [21]. Research on learning in public administration is limited and often around organizational culture, but there is some recognition of the relationship between projects and learning [26]. However, when multiple public and private organisations are involved like in the case of e-government project reforms present another level of complexity where institutional forces in that case replace the organisational structures mentioned early.

To unfold and explore PBL through the lenses of institutional theory this study aims to propose a conceptual framework that can capture both the project-based learning interactions, and the more longitudinal relationship among project actors beyond a specific project itself. This is necessary to reconcile the differences between the two approaches, PBL being short-term and contingency focuses, and institutional theory being long-term focused.

\section{The Case Study Methodology}

The case study evidence [49] for this interpretivist analysis [46] is based on the implementation of the electronic register of civil status in Albania. The multi-actor project was assisted by international donors such as the European Union, the Organization for Security and Cooperation in Europe, and Statistics Norway. This research was part of larger research project, conducted in 2010-2012, a period when the project was fully implemented and managed by the government of Albania, and the international donors.

This study started with a careful documentary review [4], analysing 74 documents consisting of national information and communication technology strategies, government programmes, project related documents, legislation, and final project reports. The review of these public materials allowed a better understanding of the projects to design the semi-structured interview strategy and questions.

The primary empirical evidence for this study was collected through semistructured interviews [22] as part of a larger project on the institutionalisation of egovernment reforms in developing countries. In total 16 interviews were conducted with government officials, top and middle project managers from the various organisations involved. This includes a focus group with 4 front and back-office employees of the General Directorate of Civil Status, the leading organisation responsible for the e-government project reform.

The documentary review and semi-structured interviews focused on three main areas informed by the earlier discussion on PBL and institutional theory: 1 . The project implementation process, 2 . Their role in it, 3. Institutionalization of practices and learning on an individual and organizational level. These three broad themes formed the basis for the coding structure and analysis of the findings [37] presented in the following section. 


\section{$4 \quad$ Findings}

The development and modernisation of the National Register of Civil Status was a very important learning process for all parties involved. The first and most obvious element was coded in the analysis of data as 'learning from abroad', referring to all the know-how brought by the international assistance, imported from outsourcing foreign companies, and lessons learned from world best practices. The reason is clearly given by a specialist in the Department of Strategy and Donors Coordination in the Council of Ministers as follows:

"It is also a security issue I would say, because if someone has tried it before, we don't need to experiment. It has a standard. Now you find the funds, you take it and treat it the same way. You don't start from A but from $Z$ and you are sure."

This statement highlights the security of implementing proven project practices, expressing confidence on the ability of Albanian authorities and users to adapt the lessons learned and changes to local needs. In this case, local parties had to make use of their experience with the old system and combine such lessons learned with a ready-given new National Register of Civil Status. Speaking in these practical terms, one of such lessons adapted in Albania were, for example, the adaptation of manuals used for the electronic register of civil status or addresses, as a specialist who worked for the General Directorate of Civil Status explains:

"But for as far as the technical part is concerned, I can say as I said before, there was a manual based on which we were working. So, a model of work was created, based on the examples of similar work models in Europe."

Local authorities were involved to create these manuals, contributing with their experience, but the 2.5 million Euros of assistance for the project came from the European Union. What appears like learning from best practices for the government, translates into enforced changes for the users. Here are two examples that support this argument. The first is a quote from an interview with a representative of the National Agency of Information Society, talking about the adaptation of e-government stages, their methodology, and evaluation in Albania:

"We have seen and analysed how Europe monitors this. [...] We have analysed these, we have tried to adjust them for our country, and this is easy for as long as you monitor the situation by monitoring the web page, because when we want to look at use, then we have to conduct surveys with the users."

Trying to understand how end-users learn the use of new systems, or even learning from them, appears difficult from her words. Instead, as many other best practices in Europe, they end up with an easy but less accurate top-down approach based on assumptions.

The second example is from a representative of the Department of Strategy and Donor Coordination in the Council of Ministers. He talks on the importance of topdown communication to promote strategies or otherwise lessons learned, and to-beimplemented reforms like the modernisation of National Register of Civil Status:

"Part of our system of integrated planning is a strategy of communication which is also on the web site. It explains how all our objectives are promoted and how it is monitored." 
Learning from and about citizens appears to be a bigger challenge for the government, than it was for end-users to become used to the new system. Indeed, objectives are developed and promoted from top to bottom, but there is no strong evidence of a parallel bottom-up approach.

The government of Albania sees a learning challenge related to the education and literacy levels. This is how a representative of the Ministry of Innovation and Information Technology explains this situation:

"The strategies in our field of information society are, how to say this, even if $20 \%$ of population will absorb them only, that is a great step, because these strategies are related not only to information technology, but also to education. Education has a great influence. But for the time it takes for the new generation to finish school and enter our cycle of policy-making, it takes at least a cycle of 10 years."

The time constrains to achieve such long-term goals tend to justify the current approach of enforced changes and adaptation. Thus, enforced fast-track learning of the electronic National Register of Civil Status appears to have been the norm during the project implementation stage. The bottom-line in terms of transfers of knowledge and learning is the utilitarian view of a project coordinator from OSCE, the donor agency, focusing on the end results:

"The system is in place and it works. [...] Regular investment into human resources are needed in terms of training, in terms of latest know-how, latest developments."

The interview where this statement was taken happened only a few months before the OSCE assistance was officially and ultimately over for this project in Albania. All the local and foreign staff like the interviewee in this case was dismissed. The system clearly works, but beyond the clear reporting picture presented by the OSCE's representative, an official of the General Directorate of Civil status has a more critical approach to the control of expertise and knowledge by the assisting third parties:

"Since OSCE started, it is helping us with trainings, financing trainings for our staff, to take over the system of the civil status, because still the system is under the control of the Austrian party. We are simply users. To acquire the knowledge to administer the system ourselves, they offer, OSCE offers support for our trainings."

Local authorities and citizens have learned how to use the electronic National Register of Civil Status. The question is whether the Albanian structures are capable of managing and further developing the system, or international assistance was and will always be indispensable. A representative of the assisting agency, OSCE, leaves the responsibility for such decisions with the Albanian parties by giving the following answer about dissemination of experiences and learning:

"Success stories implemented by Albania are ready to be multiplied in different countries, there is no doubt. So again, there are some lessons learned. Look what works, share that, see what doesn't work, what are the mistakes, inform partners about that and ask them to adjust it"

Calling the project a success story is related to its potential to be successfully disseminated elsewhere, but it is exactly the part on "inform partners about that and ask them to adjust it” that the Albanian specialist before doesn't like. The OSCE 
representative talks but is still sceptical about the learning and development of local capabilities in Albania. The former Albanian technician on the other hand perceives this policy as undermining his jobs' independence and creating a sense of dependency on international assistance.

It is clear from the evidence in this study that learning from international practices and assistance has been adapted successfully in Albania. The National Register of Civil Status was a success story in this sense being easily institutionalized among endusers. However, to preserve and advance the progress achieved so far, the policymakers must learn how to learn from citizens and understand them better. While the top-down learning has been institutionalized and disseminated, this bottom-up approach has not yet been fully integrated in the Albanian public administration.

\section{Discussion}

Operationalizing the findings of this study, the following conceptual framework based on PBL and institutional theory is proposed to have a better understanding of learning stages in e-government innovation projects.

This diagram summarizes the key lessons about institutional learning from this study. A key lesson learned is that embedding the institutional knowledge into the people and not only in the system and technology being implemented is crucial to egovernment project implementation as evidenced also by Chung et al., (2016). However, for the institutionalization of such reforms, learning should focus on local acceptance, as well as capabilities for the development and maintenance of the systems. building on existing knowledge on organizational culture and learning in public administration [26], institutional learning is explained better through the PBL approach.

This study shows that although institutionalizing the sustainability of reforms often starts with the technical assistance and involvement of the donors, it is finally shaped by the local managers and end-users. Needs and vision of the key actors are what guide the procurement and management of resources. Implementation of reforms in this regard is supported by training on accredited practices proposed by the intervention of change enablers, their expert knowledge, and most importantly some positive political will. Learning actors can be divided in two groups: supporters and resisters, influenced by the costs and benefits resulting from the change. The integration and dissemination of learning among other structures, and furthermore its institutionalization seems to depend more on their ability to coordinate their actions than on the needs of end-users. 


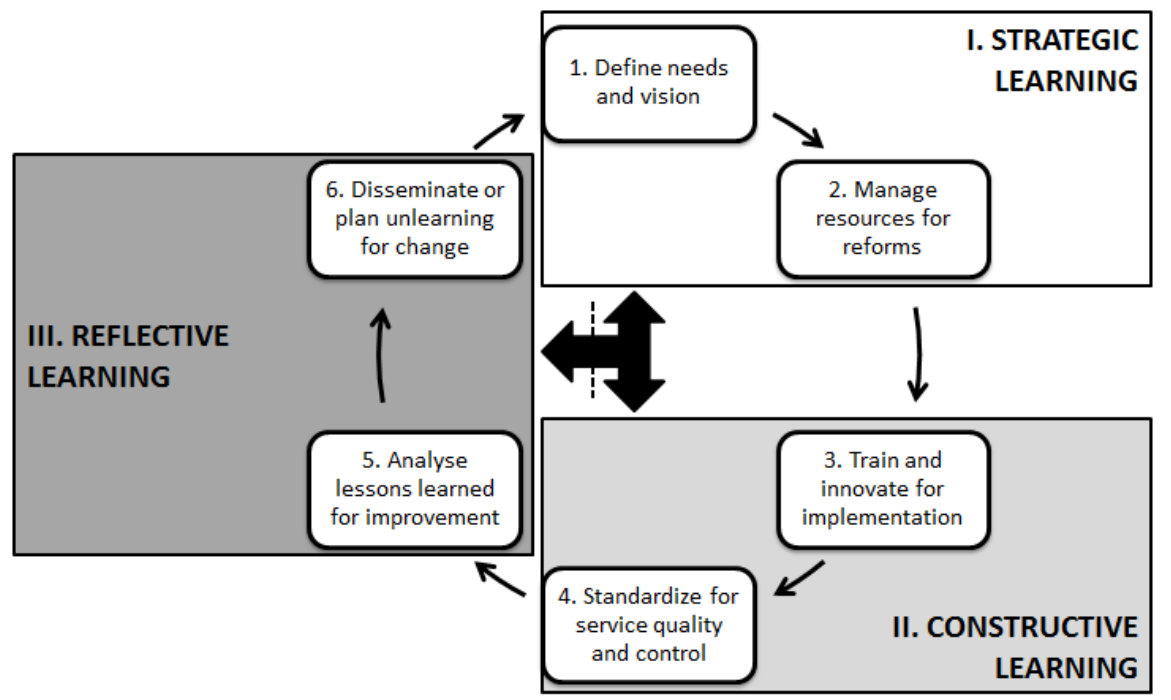

Fig. 1. Institutional learning cycle e-government innovation projects

This study shows that although institutionalizing the sustainability of reforms often starts with the technical assistance and involvement of the donors, it is finally shaped by the local managers and end-users. Needs and vision of the key actors are what guide the procurement and management of resources. Implementation of reforms in this regard is supported by training on accredited practices proposed by the intervention of change enablers, their expert knowledge, and most importantly some positive political will. Learning actors can be divided in two groups: supporters and resisters, influenced by the costs and benefits resulting from the change. The integration and dissemination of learning among other structures, and furthermore its institutionalization seems to depend more on their ability to coordinate their actions than on the needs of end-users.

Information technologies assist learning to be embedded into the very systems and automated procedures the people using them must perform, acquiring a momentum of their own. This is typical on an operational level. Yet, it is exactly this automation of learning we see in e-government reforms that raises technology above human reflection and critical thinking, thus putting at risk further development and innovation.

Unlearning appears to be one of the most difficult elements to accept and consider in the public sector, especially if it has to be applied on so-called modern structures like e-government reforms. Yet, it is a necessary process for the recognition of learned practices and validation of lessons learned. Unlearning on the other hand is a difficult but necessary process that allows further change and development in egovernment reforms [39]. Without it most structures are limited within their constructive learning stage of short-term solutions to immediate problems, automation and institutionalization of practices that tend to become irrational with time and development in other sectors. 
Undoubtedly, there has been a marked improvement in the efficiency and performance of service delivery in the two case studies. The key question here is the extent to which it can be replicated in other public sector organizations, particularly in those agencies that deliver less definable outputs or whose front-line staff have considerable discretion.

\section{Conclusion}

Reflecting on the definition of institutions given by March and Olsen as enduring collection of rules and practices around structures of meaning and resources [30], it is possible to conclude that project-based learning should become an institutionalized practice for successful multi-actor e-government reforms. This study identified three learning processes happening along project implementation stages. The first, strategic learning, happens in the beginning of the project when needs and vision are aligned with resource requirements and management to carry out the work. Secondly, constructive learning happens in the process of training people and upgrading technology while standardizing practices. Thirdly, reflective learning relates to analysis, reporting and dissemination of project outcomes, preparing the path for another cycle starting with strategic learning.

Large e-government reform projects involving multiple actors and their transformative power constitute the unique context of this study. It is in such environments where the contingency approach suggested by project-based learning can be combined with the longitudinal focus of institutional theory to re-conceptualize learning beyond classroom and organization boundaries.

Future research on multi-actor projects should pay more attention not only to learning processes related to humans, but also to machine learning capabilities of the innovative technologies we continue to implement.

\section{References}

1. Becker, J., Algermissen, L., \& Niehaves, B. (2006). A procedure model for process oriented e-government projects. Business Process Management Journal, 12(1), 61-75.

2. Becker, J., Bergener, P., Kleist, S., Pfeiffer, D., \& Räckers, M. (2008).

Evaluation of ICT investments in public administrations based on business process models. Lecture Notes in Computer Science: Electronic Government, 5184, 124-135.

3. Blumenfeld, P. C., Soloway, E., Marx, R. W., Krajcik, J. S., Guzdial, M., \& Palincsar, A. (1991). Motivating project-based learning: Sustaining the doing, supporting the learning. Educational Psychologist, 26(3-4), 369-398.

4. Bunn, F., Trivedi, D., Alderson, P., Hamilton, L., Martin, A., \& Iliffe, S. (2014). The impact of cochrane systematic reviews: A mixed method evaluation of outputs from cochrane review groups supported by the UK national institute for health research. Systematic Reviews, 3(1), 125. 
5. Chauhan, R., Estevez, E., \& Janowski, T. (2008). A model for policy interventions in support of electronic governance. Paper presented at the Proceedings of the 2nd International Conference on Theory and Practice of Electronic Governance, 199-205.

6. Chen, J., Wang, D., \& Pan, S. L. (2011). Understanding organizational agility development for Government-A process model of resource configuration. Australia: University of Queensland.

7. Chung, H., Lee, G., \& Kuo, R. (2016). Determinants of public servants' intention to adopt E-government learning. Review of Public Personnel Administration, 36(4), 396-411.

8, Dunleavy, P. (1991). Democracy. bureaucracy and public choice: Economic explanations in political science. London: Longman.

9. Dunleavy, P., Margetts, H., Bastow, S., \& Tinkler, J. (2006). New public management is dead--long live digital-era governance. Journal of Public Administration Research and Theory, 16(3), 467-494.

10. Eakin, H., Eriksen, S., Eikeland, P. O., \& Øyen, C. (2011). Public sector reform and governance for adaptation: Implications of new public management for adaptive capacity in mexico and norway. Environmental Management, 47(3), 338-351.

11. Feller, J., Finnegan, P., \& Nilsson, O. (2010). Open innovation and public administration: Transformational typologies and business model impacts. European Journal of Information Systems, 20(3), 358-374.

12. Finger, M., \& Brand, S. B. (1999). The concept of 'learning organisation' applied to the transformation of the public sector. In M. Easterby-Smith, L. Araujo \& J. Burgoyne (Eds.), Organizational learning and the learning organization: Developments in theory and practice (pp. 130-156). London: Sage Publications Limited.

13. Folke, C., Hahn, T., Olsson, P., \& Norberg, J. (2005). Adaptive governance of social-ecological systems. Annu.Rev.Environ.Resour., 30, 441-473.

14. Hassink, R., \& Lagendijk, A. (2001). The dilemmas of interregional institutional learning. Environment and Planning C, 19(1), 65-84.

15. Illeris, K. (2004). A model for learning in working life. Journal of Workplace Learning, 16(8), 431-441.

16. Illeris, K. (2010). The fundamentals of workplace learning: Understanding how people learn in working life. New York, USA: Routledge.

17. Järvinen, A., \& Poikela, E. (2001). Modelling reflective and contextual learning at work. Journal of Workplace Learning, 13(7/8), 282-290.

18. Kazanjian, R. K., Drazin, R., \& Glynn, M. A. (2000). Creativity and technological learning: The roles of organization architecture and crisis in largescale projects. Journal of Engineering and Technology Management, 17(3-4), 273-298.

19. Kefallinos, D., Lambrou, M. A., \& Sykas, E. (2009). An extended risk assessment model for secure E-government projects. International Journal of Electronic Government Research (IJEGR), 5(2), 72-92.

20 Kim, J. (2008). A model and case for supporting participatory public decision making in e-democracy. Group Decision and Negotiation, 17(3), 179-193. 
21. Kim, J., \& Wilemon, D. (2007). The learning organization as facilitator of complex NPD projects. Creativity and Innovation Management, 16(2), 176-191.

22. King, N., \& Horrocks, C. (2010). Interviews in qualitative research Sage.

23. Kriplean, T., Borning, A., Waddell, P., Klang, C., \& Fogarty, J. (2010). Supporting agile modeling through experimentation in an integrated urban simulation framework. Paper presented at the Proceedings of the 11th Annual International Digital Government Research Conference on Public Administration Online: Challenges and Opportunities, 112-121.

24. Kromidha, E. (2017). Transitions of power in multi-actor information system projects. International Journal of Project Management, 35(8), 1587-1596.

25. Kromidha, E., \& Córdoba-Pachón, J. (2017). Discursive institutionalism for reconciling change and stability in digital innovation public sector projects for development. Government Information Quarterly, 34(1), 16-25. doi:http://doi.org/10.1016/j.giq.2016.11.004

26. Mahler, J. (1997). Influences of organizational culture on learning in public agencies. Journal of Public Administration Research and Theory, 7(4), 519-540.

27. Malhotra, C., Chariar, V. M., \& Das, L. K. (2009). User centred design model (G2C2G) for rural e-governance projects. International Journal of Electronic Governance, 2(4), 378-401.

28. March, J. G., \& Olsen, J. P. (1989). Rediscovering institutions: The organizational basis of politics. New York, USA: Free Press.

29. March, J. G., \& Olsen, J. P. (1995). Democratic governance. New York, USA: Free Press.

30. March, J. G., \& Olsen, J. P. (1996). Institutional perspectives on political institutions. Governance, 9(3), 247-264.

31. March, J. G., \& Olsen, J. P. (2004). The logic of appropriateness - advanced research on the europeanisation of the nation-state. Oslo, Norway: ARENA Centre for European Studies, University of Oslo.

32. March, J. G., \& Olsen, J. P. (2006). Elaborating the "new institutionalism". In R. A. W. Rhodes, S. A. Binder \& B. A. Rockman (Eds.), The oxford handbook of political institutions (pp. 3-20) Oxford University Press.

33. March, J. G., \& Olsen, J. P. (1984). The new institutionalism: Organizational factors in political life. The American Political Science Review, 78(3), pp. 734749.

34. March, J. G., \& Olsen, J. P. (1998). The institutional dynamics of international political orders. International Organization, 52(4, International Organization at Fifty: Exploration and Contestation in the Study of World Politics), pp. 943-969.

35. March, J. G., Olson, J. P., \& Olsen, J. P. (1983). Organizing political life: What administrative reorganization tells us about government. The American Political Science Review, 77(2), pp. 281-296.

36. Metcalfe, L. (1993). Public management: From imitation to innovation. Australian Journal of Public Administration, 52(3), 292-304.

37. Miles, M. B., \& Huberman, A. M. (1994). Qualitative data analysis: An expanded sourcebook. London, UK: Sage Publications.

38. Ostrom, E. (1991). Rational choice theory and economic analysis. towards complementarity. American Political Science Review, 85(1), 238-243. 
39. Pan, G., Pan, S. L., Newman, M., \& Flynn, D. (2006). Escalation and deescalation of commitment: A commitment transformation analysis of an egovernment project. Information Systems Journal, 16(1), 3-21.

40. Poell, R. F., Van der Krogt, Ferd J, \& Wildemeersch, D. A. (1998). Solving work-related problems through learning projects. International Journal of Lifelong Education, 17(5), 341-351.

41. Pollitt, C., \& Bouckaert, G. (2011). Public management reform: A comparative analysis-new public management, governance, and the neo-weberian state OUP Oxford.

42. Reddick, C. G. (2011). Citizen interaction and e-government: Evidence for the managerial, consultative, and participatory models. Transforming Government: People, Process and Policy, 5(2), 167-184.

43. Shepsle, K. A. (1989). Studying institutions. Journal of Theoretical Politics, 1(2), 131-147.

44. Thomas, J. W. (2000). A review of research on project-based learning. San Rafael, California: The Autodesk Foundation.

45. Vurro, C., Dacin, M. T., \& Perrini, F. (2010). Institutional antecedents of partnering for social change: How institutional logics shape cross-sector social partnerships. Journal of Business Ethics, 94, 39-53.

46. Walsham, G. (1995). Interpretive case studies in IS research: Nature and method. European Journal of Information Systems, 4(2), 74-81.

47. Wimmer, M. A. (2006). Implementing a knowledge portal for e-government based on semantic modeling: The e-government intelligent portal (eip. at). Paper presented at the System Sciences, 2006. HICSS'06. Proceedings of the 39th Annual Hawaii International Conference on, , 4 82b.

48. Yin, R. K. (2009). Case study research: Design and methods (4th ed.). London, UK: Sage Publications. 